Pamiętnik Literacki 2021, 2, s. 123-142

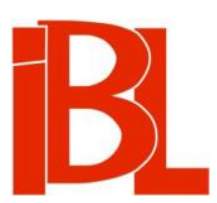

\title{
Spazmy i wapory w literackich kreacjach polskich pisarzy XVIII i XIX wieku
}

Bożena Mazurkowa 
Pamiętnik Literacki CXII, 2021, z. 2, PL ISSN 0031-0514

DOI: $10.18318 / \mathrm{pl} .2021 .2 .9$

BOŻENA MAZURKOWA Uniwersytet Śląski, Katowice

\section{SPAZMY I WAPORY W LITERACKICH KREACJACH POLSKICH PISARZY XVIII I XIX WIEKU}

Sięgające tradycji antyku, a w języku francuskim zadomowione w liczbie mnogiej nazwy: „spazmy” i - dość dziwnie brzmiące już dziś - „wapory”, w naszym rodzimym piśmiennictwie XVIII-wiecznym bardzo często wymieniano łącznie. Określano nimi ówcześnie konkretne dolegliwości, które w Encyclopédie, ou Dictionnaire raisonné des sciences, des arts et des métiers [...] uhonorowane zostały odrębnymi, stosunkowo długimi hasłami o ambicjach naukowych ${ }^{1}$. Wapory w medycynie oznaczały oddziałująca na mózg chorobę, która dotykała przedstawicieli obu płci, ale miała u nich różne i odmiennie zlokalizowane przyczyny. U mężczyzn nazywano ją hipochondrią (rozprzestrzeniającą się „z dolnych części brzucha, zwłaszcza podżebrza”), a u kobiet - „dolegliwościa lub dusznościa histeryczną, która pochodziła z macicy”. Uważano, że choroba ta wywoływana była „przez łatwo przenikające opary”, które ze wskazanych miejsc przemieszczały się do mózgu, mącąc go oraz wypełniając „dziwnymi i ekstrawaganckimi pomysłami, zwykle nieprzyjemnymi”. Przy czym te „rzekome opary” z czasem - gdy przekonanie o ich istnieniu zostało „obalone przez teorię i anatomię" - uznano za podrażnienia włókien nerwowych narządów wewnętrznych, co niezawodnie miało wpływać na mózg². Za jeden ze

1 Warto nadmienić, że hasła te nie znalazły się w wydanych współcześnie w polskim przekładzie wyborach materiałów z francuskiej publikacji. Zob. Encyklopedia albo Słownik rozumowany nauk, sztuk i rzemiost, zebrany z najlepszych autorów, a szczególnie ze słowników angielskich Chambersa, d'Harrisa, de Dyche i innych, przez stowarzyszenie ludzi nauki. Uporzadkowany i wydany przez pana Diderot, a jeśli chodzi o część matematyczna przez pana d'Alembert z Paryskiej Akademii Królewskiej Nauk i z Berlińskiej Akademii Królewskiej. (Wybór). Przeł. z oryginału francuskiego i przypisami opatrzyła E. Rzad k ow ska. Wstęp J. Kott. Wrocław 1952. BN II 73. - Encyklopedia albo Stownik rozumowany nauk, sztuk i rzemiost, zebrany z najlepszych autorów, a szczególnie ze słowników angielskich Chambersa, d'Harrisa, de Dyche i innych, przez stowarzyszenie ludzi nauki. Uporzadkowany i wydany przez pana Diderot, a jeśli chodzi o część matematyczna przez pana d'Alembert z Paryskiej Akademii Królewskiej Nauk i z Berlińskiej Akademii Królewskiej. Wybór artykułów. Wyboru dokonał i komentarzami opatrzył A. S o b o ul. [Przeł. J. Ro g o zi ń s ki (artykuły Encyklopedii), J. G u ra now ski (wstęp i komentarze)]. Warszawa 1957.

2 Encyclopédie, ou Dictionnaire raisonné des sciences, des arts et des métiers, par une société de gens de lettres. Mis en ordre et publié par M. Diderot, de l'Académie Royale des Sciences et des BellesLettres de Prusse, quant à la partie mathématique par M. d'Alembert, de l'Académie Royale des Sciences de Paris, de celle de Prusse, et de la Société Royale de Londres. T. 16: Teanum-Vénerie. Paris 1765, s. 836-837 (hasło: Vapeurs). Przekład haseł z francuskiej encyklopedii - J. Plu ta. W dziele B. de Mand eville' a A Treatise of the Hypochondriack and Hysterick Passions (Traktat o namiętnościach hipochondrycznych i histerycznych, 1711), napisanym zgodnie $z$ dawnym 
skutków waporów uważano właśnie spazmy, czyli nagłe, nienaturalne skurcze dolnej części ciała ${ }^{3}$.

W Polsce zjawiska łączące się $\mathrm{z}$ waporami i spazmami przynależały w niewielkim zakresie do obszaru stricte medycznego czy filozoficznego ${ }^{4}$. Przez pisarzy oświeceniowych traktowane były raczej jako swoiste zwiastuny pewnych elementów i fenomenów charakterystycznych dla stylu życia wyższych sfer, przede wszystkim kobiet podążających za modą dyktowaną przez Paryż. Jak pisze Marian Skrzypek:

Wiek XVIII we Francji, jak i niemal w całej Europie, to wiek mody na histerię. Wśród kobiet francuskich panuje „epidemia” waporów. Polskie arystokratki cierpią na spazmy [...]. W Anglii panuje spleen. Wśród żołnierzy szwajcarskich służących za granicą szerzy się Heimweh, chorobliwa tęsknota za ojczyzną, powodująca często obłęd i śmierć.

Wiek XVIII, a zwłaszcza pierwsza jego połowa, to okres, w którym pojawiają się zbiorowe psychozy religijne, idące w parze $z$ modą na wapory i konwulsje, które przejawiają się nie tylko w dziedzinie religii, ale stanowia problem obyczajowy niemal w całej Europie ${ }^{5}$.

W polskich realiach drugiej połowy XVIII wieku zasadniczo mamy właśnie do czynienia z tym ostatnim, obyczajowym aspektem sygnalizowanego problemu. Dlatego też w przypadku spazmów bardziej adekwatna wydaje się nie stricte naukowa definicja zaczerpnięta przez Samuela Bogumiła Lindego z pracy Jędrzeja Krupińskiego Splanchnologia lub nauka o trzewach $w$ ciele człowieczym się znajdujacych z przydatkiem wykładów fizjologicznych (Lwów 1775) ${ }^{6}$, lecz zamieszczona w Słowniku warszawskim, dotycząca tego terminu w liczbie mnogiej, uwaga o drgaw-

stanem wiedzy, mowa m.in. o tym, że „wapory uteryczne (od łac. uterus - macica) tłumaczono oparami poirytowanej macicy, które uderzają kobietom do głowy, powodując spazmy, zadyszkę, skurcze kloniczne, drżenia oraz inne symptomy znamienne dla histerii” (M. Skrzypek, Oświeceniowa kategoria przesadów. Z Ciemnogrodem Potockiego $w$ tle. „Studia Wilanowskie” t. 19 $\langle 2012\rangle$, s. 15). Zob. też E. Trillat, Historia histerii. Przeł. Z. Podgór s ka-Klaw e, E. J a mr o zi k. Wrocław 1993, s. 45-66 (rozdz. 3: Duchy zwierzęce i wapory).

3 Zob. Encyclopédie, ou Dictionnaire raisonné des sciences, des arts et des métiers, t. 15: Sen-Tchupriki, s. 434-438 (hasło: Spasme).

$4 \quad$ Funkcjonujące w Polsce od XVI wieku aż po koniec okresu przedwojennego nazwy przypisywanych przedstawicielkom płci pięknej dolegliwości psychicznych i fizycznych, które do XVIII stulecia łączono z zaburzeniami pracy macicy, metodą semazjologiczną zbadała Z. Krótki w artykule Średnio- i nowopolskie nazwy dolegliwości kobiecych („Annales Universitatis Paedagogicae Cracoviensis. Studia Linguistica” $13\langle 2018\rangle$; rozważania dotyczące spazmów i waporów zamieszczone są na s. 79-80).

5 M. Sk rzy pe k, Filozofia Diderota. Warszawa 1996, s. 57, 210. Jak stwierdza badacz, do połowy XVIII wieku większość patologicznych stanów psychicznych, które zostały wymienione w przytoczeniu, ówcześni lekarze filozofowie łączyli „Z zaburzeniami na tle seksualnym”. Z takich przekonań wywodzą się wypowiedzi Diderota na temat histerycznych waporów (vapeurs histériques): „to przecież - etymologicznie rzecz ujmując - opary wydzielane przez macicę (z greckiego - histera), zatruwające mózg i powodujące zaburzenia w jego funkcjonowaniu". W czasach Diderota ta teoria „była już przeżytkiem, ale dawna terminologia pozostała” (ibidem, s. 57-58). Postęp wiedzy medycznej spowodował, że „zrywając z tradycją, przeniesiono siedlisko histerii z macicy do mózgu”, co wiązało się z rozwojem nowożytnych teorii neurologicznych (Trillat, op. cit., s. 46).

6 S. B. Lin de, Stownik języka polskiego. Wyd. 2, poprawne i pomnożone. T. 5: R-T. Lwów 1859, s. 375 (hasło: Spazm): „kurcz; [...] ciagnienie gwałtowne części myszczastych [tj. 'mięśniowych'], tak iż część naturalnie miękka twardnieje”. $Z$ tym znaczeniem powiązane zostało również podhasło Spazmatyczny, którego sens oddaje wyrażenie „spazmowe ruchy”, skojarzone z konwulsjami (ibidem). 
kach oraz następująca informacja w punkcie drugim: „Gwałtowne i niepohamowane łkanie $z$ omdleniem, $z$ śmiechem nerwowym” ${ }^{7}$. W przypadku określeń „wapor” i „waporek” Linde, uwzględniając pochodzenie terminów $\mathrm{z}$ łaciny medycznej (,vapor" - 'opar, para wodna'), a tym samym ich pierwotny sens, odsyła do trzech haseł: Wyziew, Wydech, Para. Natomiast interesujące nas, przenośne znaczenie ma podana tam francuska nazwa w liczbie mnogiej: „les vapeurs" ${ }^{8}$, z czasem, podobnie jak odnotowany jej synonim „spazmy”, odnoszona do objawów rzekomego bólu, a zatem łączona $\mathrm{z}$ atakami histerii. Pełniejsze objaśnienie tego słowa daja autorzy Słownika warszawskiego, podobnie jak poprzednio uwzględniając realia obyczajowe epoki. Oprócz znaczeń, które odnotował Linde, podano tu następującą definicję waporów: „choroba osób zbyt pieszczonych, fumy, spazmy itp.” ${ }^{9}$ Do tych dolegliwości osób (głównie kobiet) z towarzystwa należałoby jeszcze dodać migrenę oraz supiry (fr. „soupir”), czyli westchnienia, a także wspomniane już fumy, rozumiane analogicznie do waporów bądź jako „próżna rzecz, [...] próżność” ${ }^{10}$, „nadętość, grymasy"11.

Zwięzłe definicje wymienionych dotąd modnych przypadłości zasadniczo pozostaja $\mathrm{w}$ zgodzie $\mathrm{z}$ przedstawiona we francuskiej encyklopedii $\mathrm{z}$ epoki charakterystyką osób narażonych na wapory oraz przyczyn szerzenia się tej dolegliwości:

trzeba zauważyć, że wa pory atakuja przede wszystkim ludzi o próżniaczym ciele, którzy niewiele męczą się pracą fizyczną, za to dużo myślą i marzą: ludzi ambitnych, o żywym umyśle, przedsiębiorczych, wielbicieli dóbr i życiowych uciech, ludzi pióra, uzdolnionych, duchownych, dewotów, ludzi wyczerpanych rozpustą bądź też nadmierną praktyką, kobiety, które oddają się próżniactwu i za dużo jedzą wszyscy oni są podatni na wa pory, ponieważ u niewielu z nich ćwiczenia i ciężka praca fizyczna blokują szkodliwy wpływ soku nerwowego. Wielu ludzi myśli, że choroba ta atakuje raczej umysł niż ciało i że ból to kwestia wyobraźni. Trzeba przyznać, że rzeczywiście najważniejszą jej przyczyna jest nuda i szalona namiętność, ale z czasem, gdy choroba toczy umysł, zmusza również ciało do współudziału; w wyobraźni czy w rzeczywistości ciało wycieńcza się. Choroba jest dzisiaj bardziej powszechna niż kiedykolwiek, ponieważ skłania do tego w większym stopniu błędne kształcenie płci, młodzi ludzie oddają się albo namiętności nauki albo zupełnie innej z tym samym szałem, bez kalkulacji i rozsądku; ich umysł osłabia się, zanim zostanie ukształtowany, ledwo narodzony staje się bezsilny. Łakomstwo, próżniacze życie i zwykłe przyjemności podtrzymują tę nieszczęsną namiętność, aby uchodzić za pięknoducha; w a p ory atakują ciało, rujnuja je i powodują wyniszczenia ${ }^{12}$.

Podobnie jak w przypadku przywołanej wypowiedzi Skrzypka, we wszystkich współczesnych komentarzach, które w edycjach tekstów XVIII-wiecznych poświęcone są spazmom, objaśnienia w części początkowej lub końcowej odsyłają do

7 Stownikjęzyka polskiego J. Karłowicza, A. Kryńskiego i W. Niedźwiedzkiego. T. 6: S-Ś. Ułożony przez W. Niedźwiedzkiego, z udziałem K. Króla. Warszawa 1915, s. 285 (hasło: Spazm).

8 Lind e, op. cit., t. 6: U-Z (1860), s. 218 (hasło: Wapor, waporek).

9 Słownikjęzyka polskiego, t. 7: T-Y (Ułożony przez W. Ni e dź wi e d z k i e g o. 1919), s. 457 (hasło: Wapor).

10 Lind e, op. cit., t. 1: A-F (1856), s. 677 (hasło: Fum): „dym, wyziew para”; mieć fumy w głowie mieć „urojenia, marzenia”.

11 Słownik języka polskiego, t. 1: A-G (Ułożony pod red. J. Karłowicza, A. Kryńskiego i W. Niedźwiedzkiego. 1900), s. 781 (hasło: Fumy); t. 6, s. 515 (hasło: Supir).

12 Encyclopédie, ou Dictionnaire raisonné des sciences, des arts et des métiers, s. 837 (hasło: Vapeurs). 
wystawionej we Lwowie w roku 1797 sztuki Spazmy modne Wojciecha Bogusławskiego, a niekiedy cytowany jest fragment jego wypowiedzi ze wstępu do tej komedii. Nie ulega bowiem wattpliwości, że najpełniej, i to zarówno w formie dyskursywnej, jak i stricte literackiej, spazmy scharakteryzował u nas właśnie Bogusławski najpierw we wstępie, zatytułowanym Powody napisania komedii "Spazmy modne”, a później w samej sztuce: poprzez kreację bohaterów oraz konkretnych scenek. W tonie na wpół żartobliwym, na wpół ironicznym wyjaśniał on w drugim tomie swoich Dziet dramatycznych (1820), że przed 20 laty, a zatem na przełomie XVIII i XIX stulecia, zapadanie kobiet na „modne” dolegliwości nie było rzadkością:

spazmy, migrena i drżenie serca tak powszechna prawie po wszystkich wyższych domach były chorobą, że ją nieledwie epidemiczna nazwać można było ${ }^{13}$.

Wprawdzie, jak dopowiada pisarz z udawana powagą, lekarze spieszyli z pomocą wielu „cierpiącym pięknościom”, lecz „nie dali nam objaśnienia” tej choroby. Nie zmieniając tonu, bliżej nieznanych powodów owego braku autor upatrywał m.in. w takich zjawiskach, jak „złość powietrza czyli dobroć mężów, czyli na koniec niezręczne sprawowanie się ówczesnych amantów"14. Zarówno tytułowa formuła (oznaczająca popularny w wyższych warstwach zespół zachowań, z nadmierną afektacją jedynie naśladujących zewnętrzne objawy rzeczywistego, poważnego schorzenia), jak i wskazane przez pisarza przypuszczenia dotyczace przyczyn tak częstego występowania symptomów charakterystycznej dla epoki „choroby” jednoznacznie zaświadczają, że wspomniane dolegliwości, przypisane tu wyłącznie kobietom, oświeceniowy twórca traktował jako pozy, udawane głównie w celu wymuszenia przez przedstawicielki płci pięknej konkretnych działań i postaw domowników (służby i mężów) oraz adoratorów. Z nieukrywaną kpiną, aczkolwiek połączoną $z$ nienaganną elegancją wysłowienia, Bogusławski snuł rozważania nad ta „szkodliwą społeczeństwu słabością:

To wszelako było istotną prawdą, która się nie tylko poznać, ale nawet wielu mężom, a najprzykrzej służącym uczuć dawała, że ta choroba zjawiała się zazwyczaj wtenczas, kiedy jej potrzeba było. Każde nieledwie niezadowolnienie [...] sprowadzało ją natychmiast. Często używaną była za sposób usprawiedliwienia się z jakowych zarzutów, a częściej jeszcze za sposobność zasłużenia na nie [...]. Jeżeli gdzie zobaczono niespodziewanie nowy ekwipaż, nowe brylanty, nowego przyjaciela, zaraz się domyślano - bo czegóż się nie domyśla złość ludzka! - że tam spazmy albo migrenę leczyć musiano ${ }^{15}$.

Dodajmy, że kilkanaście lat później w mistyfikacyjnym liście do redakcji „Kroniki Emigracji Polskiej” autor używający znaczącego pseudonimu Sylwester Pigułka wspomniał o spazmach, z satyryczno-ironiczną intencją pisząc o chorobach trawiących polską emigrację popowstaniową na Zachodzie. Podzielił te dolegliwości, a w rzeczywistości obserwowane w rodzimym środowisku na obczyźnie pewne wynaturzenia i mody o charakterze społecznościowym, politycznym i literackim, na trzy rodzaje: „zarazy, czyli tak zwane epidemie porywajace całe masy” (braterstwomania, republikomania), ,choroby indywidualne” (komitetomania i centralizomania)

W. B og u sła w ski, Powody napisania komedii „Spazmy modne”. W: Dzieła dramatyczne. T. 2. Warszawa 1820, s. 154.

15 Ibidem, s. 154-155. 
oraz „choróbki, słabostki, przemijające, modne, niegrożące żadnym niebezpieczeństwem" (dyplomacjomania, religiomania, klubomania i pamiętnikomania). Wśród tych ostatnich, z wyraźną intencją żartobliwą wskazał dolegliwości, które mogą mieć poważne konsekwencje „w przypadku wielkiego zaniedbania” - i tu właśnie wymienił jednym tchem, bez dodatkowej charakterystyki: „spazmy, katary i zawroty głowy"16.

Spazmy wraz z waporami maja, rzecz jasna, swoją wcześniejszą historię w literaturze oświeceniowej. W odniesieniu do drugiej dolegliwości świadczy o tym choćby zamieszczona w słowniku Lindego egzemplifikacja zaczerpnięta ze sztuki Pierre’a Beaumarchais'go, w przekładzie Mikołaja Wolskiego zatytułowanej Dzień pusty albo Wesele Figara (1786). Zuzanna, ukochana tytułowego bohatera i zarazem służąca Hrabiny, w jednej ze scen prosi jej męża o lekarstwo dla swojej pani, która właśnie „zachorowała na wapory” ${ }^{17}$. Na zalecenie Hrabiego (który sądził, że Figaro porzuci dziewczynę dla Marceliny), aby zatrzymała także dla siebie specyfik leczący tę niedyspozycję, zdroworozsądkowym komentarzem jednoznacznie wiąże ona wspomnianą przypadłość $\mathrm{z}$ obyczajami modnych dam $\mathrm{z}$ towarzystwa:

ZUZANNA

Alboż to kobiety mojego stanu chorują czasem na wapory? Wszakże to choroba wyższej kondycji, która się nie nabywa tylko w budoarach? [akt III, sc. 7] $]^{18}$

Opublikowany w numerze 36 „Monitora” z 6 V 1767 [Diariusz damy modnej] $z$ tygodniowymi zapisami od poniedziałku do niedzieli zawiera adnotacje dotyczące złego humoru bohaterki artykułu (po odebraniu listu od męża) i ciężkiej migreny ${ }^{19}$. Natomiast ani słowa o spazmach i waporach. A jednak obie dolegliwości $z$ przekąsem łączono z podążającymi za modą mieszkankami stolicy, gdzie (jak dwa miesiące wcześniej, w numerze 21 „Monitora”, z 14 III 1767, stwierdził bliżej nieznany publicysta):

Jedno przeciw modzie wykroczenie wyszydza zaraz dobrze urodzoną osobę, cóż dopiero ustawicznie wykwintności przestępstwo? [...] Łatwo tam występki grube przebaczane bywają, ale przestępstwa mody nigdy nie darują ${ }^{20}$.

W satyrycznym portrecie wychowanej na prowincji osoby „wyższego ekstraktu” wymienione tu zostały „w d zi ie ki za pa ch u przez zażywanie wódek i balsamów na to sporządzonych”, „wdzięki w mówieniu” (głównie po francusku), „wdzięki wymyślania” (sprzeczne ze stałością przyzwyczajeń), „wdzięki utyskiwania na złe, które się cierpi”, „wdzięki uskarżania się

$$
\text { drow }
$$
była Ludwika z Zyberków Borchowa vel Borgowa (zm. 1788), starościanka bolnicka, żona Jana Jęnitorze” (1765-1770). Oprac. E. Al e k s a n d ro w s k a. „Pamiętnik Literacki” 1976, z. 3, s. 184-185. 
na złe, którego nie cierpiemy” oraz „wdzięki w lękaniu się”21. I w odniesieniu do tych przedostatnich kpiacy $z$ modnych dziwactw publicysta, udający w artykule osobę całkowicie zdegustowaną i zażenowaną brakiem ogłady oraz parafiańskimi obyczajami tytułowej postaci, pisał o niej:

Pół roku przepędziła nie skarżąc się na migrenę; to jeszcze daruję, ale że przez ten czas na spazmy, na wapory nie stękała, tego wybaczyć nie mogę, bo tak czynić jest na złe zażywać zdrowia ${ }^{22}$.

A zatem bodaj najwcześniej spazmy i wapory do polskiego piśmiennictwa na szersze forum wprowadziła, jak można mniemać, publicystyka „Monitora”. Do tejże problematyki, z satyryczną intencją podjętej w stołecznym piśmie „moralnym”, nawiązał Franciszek Bohomolec w komedii Monitor, wydanej również w 1767 roku. W jednoaktowej sztuce jedna $\mathrm{z}$ mieszkanek Pustkowa skarży się na związanego ze stolica pana Monitora, który miał się tam zatrzymać w drodze do Lwowa:

\section{UMIZGALSKA}

Nikomu on tak nie dopiekł jak mnie! Czy nie jest to złość ostatnia żartować z tego, że ja często cierpię migrenę, spazmy i wapory? Co ja temu winna, że podlegam tym słabościom? ${ }^{23}$

Obie dolegliwości przypisywano w epoce i nadal się przypisuje, zwłaszcza po wypowiedzi Bogusławskiego ze wstępu do Spazmów modnych, przede wszystkim ówczesnym kobietom, i to żyjącym w miastach, skądinąd postrzeganych jako siedlisko szerzącego się zepsucia, złych nawyków i postaw oraz różnych dziwactw, a szczególnie paniom mieszkającym w stolicy. W takim duchu utrzymane są w Chudym literacie Adama Stanisława Naruszewicza wyjaśnienia przybyłego z prowincji do Warszawy szlachcica, który u księgarza ulicznego oprócz driakwi (panaceum na wszelkie dolegliwości) i kalendarza $z$ informacjami o chorobach poszukuje publikacji z opisem spazmów. Na tę przypadłość, zaraźliwą i dotkliwą (skoro mąż gotów jest kupić druk poświęcony owej dolegliwości), wzorem stołecznych dam cierpi jego żona, jak bowiem ów szlachcic stwierdza:

\section{Dwa razy tylko była mi w Warszawie, alić}

nie może, biedna, spazmów od siebie oddalić. [w. 151-152] ${ }^{24}$

$\mathrm{Na}$ to, że nieodpowiednie wzorce postępowania na wieś przychodzą $\mathrm{z}$ miast, a szczególnie ze stolicy, utyskuje z kolei Pan Spokojski w sztuce Ignacego Krasickiego Po modnemu. Wielkomiejski styl życia à la mode reprezentują tutaj trzej kawalerowie o znaczących nazwiskach: Wiatrakowski, Uśmiechiewicz i, wygłaszający rymowane maksymy, Żartuliński. Ten ostatni, po przybyciu do domu Pana Spokojskiego, obwieszcza pierwszemu z wymienionych stołeczne nowiny: „Kasztelanowa od dwóch niedziel raz wraz na migrenę chora, księżniczka ma spazmy" (akt I, sc. 7) ${ }^{25}$.

21 Wodnicki, op. cit., s. 147-148.

22 Ibidem, s. 148.

23 F. Bo ho mole c, Monitor. Komedia w jednym akcie. Warszawa 1767, s. 25.

24 A. Naruszewicz, Chudy literat. W: Poezje zebrane. T. 3. Wyd. B. Wols ka. Warszawa 2012, s. 144 .

25 I. Krasicki, Po modnemu. W: Dzieła zebrane. T. 4: Komedie. Oprac. J. T. Pokrzywniak. Poznań 2016, s. 281. 
Na temat modnych wówczas dolegliwości, które panie $\mathrm{z}$ towarzystwa $\mathrm{z}$ upodobaniem odnajdywały w sobie i uzewnętrzniały w osobliwym zachowaniu w celu pozyskania przychylnej uwagi, wypowiedział się również Franciszek Salezy Jezierski. Definiując choroby w słownikowym dziele Niektóre wyrazy porzadkiem abecadła zebrane i stosownymi do rzeczy uwagami objaśnione (1791), z pobłażliwością nawiązał do beztroskiego stylu życia kobiet i w tonie ironicznym odniósł się do przypadłości udawanych przez nie, jak można sądzić - w salonowej scenerii:

prócz chorób złączonych z własnością natury, są choroby wymysłów i dziwactw. Kobiety, ta płeć lubiąca próżnowanie i próżność, jakby na usługę wdzięków swoich powymyślały spazmy, wapory i insze dziwactwa słabości, właśnie żądając tego, aby wymysły skrzywienia się i zmyślane stękania wymagały koniecznie dla nich w postaci politowania nowo pozyskanego pochlebstwa ${ }^{26}$.

Wydaje się, że ze względu na swego rodzaju teatralizację zachowań, łączonych w epoce (tak właśnie jak wypowiedzi Jezierskiego) z silnie nacechowanymi afektacją spazmami eleganckich kobiet $z$ wyższych sfer, dziełami niejako ze swej natury przystosowanymi do ukazywania takich oznak modnej dolegliwości były komedie. O tejże przypadłości wspominają m.in. dwaj autorzy sztuk reprezentujących „komedię obyczajową warszawską". W utworze Wet za wet (1787) Grzegorza Broniszewskiego służący Szambelana na wieść o tym, że w ręce pana dostały się listy pisane przez jego małżonkę do porucznika Trzpiotowskiego, taki sposób ratowania Szambelanowej podaje jej służącej Agatce:

\section{ZWROTNICKI}

Chybaby ten jeden: jak przyjdzie, wpadnijcie z góry na niego obydwie, zakrzyczcie go, zahałasujcie, zagłuszcie; na koniec ty padnij i zemdlij, jejmość niech na spazmy zachoruje. To jest cała broń wasza, innej nad tę nie widzę. [akt III, sc. 7] ${ }^{27}$

W drugiej ze wspomnianych sztuk - komedii Umizgi dla przysługi (1788) Jana Drozdowskiego - stykamy się ze spazmami, które nie zostały „zaplanowane” na podstawie łączonych $z$ tą niedyspozycją charakterystycznych, powtarzalnych oznak uzewnętrznianych przez konkretne zachowanie i gestykulację. Tu w stołecznym domu Rozsądnickiego córka gospodarza, Karolina, na (fałszywą zreszta) wieść o tym, że darzony przez nią uczuciem Walery zainteresowany jest jej leciwą ciotką, wdową Sknerska, omdlewa i w sposób, by tak rzec, „widowiskowy” przeżywa miłosny zawód. Poznajemy to z relacji służącej Helenki, która na pytanie Melissy, drugiej córki gospodarza, co dolega siostrze, odpowiada:

\section{HELENKA}

Nie wiem, lecz słabość ta niepospolita!

Rzuca się, krzyczy, jęczy, za serce się chwyta,

Mruczy coś o Walerym, lecz niezrozumiale. [akt I, sc. 6] $]^{28}$

Fawory (służący panicza Walerego), który nieopatrznie przekazaną nowiną tak

F. S. J e zi i r s ki, Niektóre wyrazy porzadkiem abecadła zebrane i stosownymi do rzeczy uwagami objaśnione. W: Wybór pism. Oprac. Z. S k w a r c zy ń s ki. Wstęp J. Zi o m e k. Warszawa 1952, s. 143 (hasło: Choroba). 
fatalnie „przysłużył się” Karolinie, zupełnie inaczej, niemal z rozrzewnieniem postrzega przejawy udramatyzowanej afektacji panny:

\section{FAWORY}

Wtem, niebożątko, nagle zapadła w niezdrowie.

Ach, widzieć tam w jej pięknych liczkach odmian wiele,

Owe łzy, łkania, owe zbyt żałosne trele... [akt I, sc. 8] ${ }^{29}$

W rozmowie, którą w tejże scenie prowadzi Fawory z ojcem Walerego, dopełniona zostaje deskrypcja oznak nagłej choroby panny i wskazane są rzeczywiste powody podjęcia swoistej gry (z pełną świadomością obserwowania jej przez otoczenie), jaka de facto była modna przypadłość, trafnie rozpoznane przez konkurenta Sknerskiej, nomen omen - Wieśniackiego:

WIEŚNIACKI

Czy to nie będą modne spazmy? Hę?

FAWORY

Któż zgadnie?

Trelik w jęku, gdyby z nut, krzyżuje się ładnie;

Słowem, cale do twarzy jest jej ta choroba.

WIEŚNIACKI

Przeto też może się jej być słabą podoba.

Figlarny świecie! [akt I, sc. 8] ${ }^{30}$

Także w Powrocie posła (1790) Juliana Ursyna Niemcewicza reakcja Starościny na wieść, że małżonek niezbyt przychylnie odnosi się do jej zamysłu wzniesienia modnej kaskady w miejscu, gdzie stoi przynosząca dochody karczma, ma wszelkie znamiona spazmów, chociaż sama ta nazwa nie pada w sztuce:

$$
\begin{gathered}
\text { STAROŚcina } \\
\text { To dla mnie jest wstydem, } \\
\text { Że tego na Waćpanu wyprosić nie mogę. } \\
\text { Rzuca się na krzesło i omdlewa } \\
\text { Je suis mal, je me meurs! } \\
\text { STAROSTA } \\
\text { krzyczy } \\
\text { Ratujcie niebogę. } \\
\text { Przybiega Agatka i lokaj, daja jej wachać wódkę i ratuja } \\
\text { Trzeba prędko zapobiec tej nagłej chorobie. } \\
\text { Krzyczy jej do ucha } \\
\text { Jutro Żyda wypędzę i kaskadę zrobię! } \\
\text { Niechaj się uspokoi me drogie serduszko... } \\
\text { Nie przychodzi do siebie! Nieście ją na łóżko! } \\
\text { Wynosza Starościnę z krzesłem [akt II, sc. 9] }{ }^{31}
\end{gathered}
$$

Wprawdzie oznaki spazmów rzeczywiście ujawniały się niespodzianie, ale w dużej mierze były przewidywalne. Dolegliwość ta - jak stwierdził Bogusławski - „nie

31 J. U. Ni e m ce wi c z, „Powrót posła. Komedia $w$ trzech aktach” oraz wybór bajek politycznych. Oprac. Z. Skwarc zyń ski. Wyd. 10. Wrocław 1983, s. 72-73. BN I 4. 
w krwi, nie w ciele, ale w umysłach miała swoje siedlisko"32. Powstawała pod wpływem określonych faktów i okoliczności zewnętrznych, nietolerowanych bądź źle znoszonych przez konkretne osoby. W sztuce Spazmy modne Dorotka, garderobiana Hrabiny, chociaż nie pozostawała w „służbie Galena”, w rozmowie z wykrzykującym na „przeklętą służbę” kamerdynerem Hrabiego Modnickiego bez namysłu podała powód wielorako uciążliwej, a przy tym udawanej choroby swej pani, co też zaakcentował rozsierdzony współrozmówca dziewczyny:

DOROTKA

A cóż tam? czy zdrowsza? [...]

SLUŻALSKI

A gdzie tam! Coraz gorzej wrzeszczy i rzuca się jak nawiedzona

DOROTKA

Póki tylko mąż nie wyjdzie, póty ona będzie w spazmach leżała. Wszakże zdrowiuteńka była, nim on przyszedł

SŁUŻALSKI

Bodaj szatani porwali modne spazmy, wapory, drżenie serca, migreny, konwulsje i tych wszystkich, co je powymyślali! Człowiek oka zmrużyć nie może. Ledwo świt, wstawaj, pal ogień, grzej serwety, lataj po doktora, znoś kordiały. [akt I, sc. 1] ${ }^{33}$

Warto nadmienić, że w brulionowej wersji Zabobonnika Franciszka Zabłockiego (pierwotnie tytuł brzmiał: Zabobonny) spazm został również wymieniony wśród rozlicznych chorób, o których źródła doktor Recepta pyta Frantowicza, udającego cyrulika świetnie obeznanego ze sztuką lekarską:

RECEPTA

Skąd petocie, skąd kancer, skąd zawroty głowy,

$Z$ czego jest katar obcy, z czego narodowy,

Skąd kaduk, spazm, migrena, skąd kurcz, pituita,

Skąd ospa wielka, mała, szczepiona, nabyta?... [akt III, sc. 10] ${ }^{34}$

W ostatecznej wersji sztuki Zabłocki usunął jednak „spazm”, dając następującą lekcję trzeciego z przytoczonych wersów: „Skąd kaduki, migrena, skąd kurcz, pituita”. Zadecydowała o tym, jak można sądzić, nie tyle niechęć do modnej przypadłości, ile fakt, iż w tym samym wersie znajdowała się tożsama znaczeniowo nazwa - „kurcz”.

Nie tylko Bogusławski, ale także inni literaci oświeceniowi z ironicznym przekąsem, a nawet kpina pisali przede wszystkim o kobiecych spazmach, którym nierzadko towarzyszyły krzyki, żałosne jęki i w końcu - omdlenia. Takie zachowanie pełne afektacji i ostentacji współgrało $z$ emocjonalną aurą, jaką pod wpływem lektur romansowych zgodnie $z$ panujaca modą wytwarzały wokół siebie kobiety z wyższych sfer i postaci na ich wzór kreowane przez autorów. Ale nie tylko one. Na spazmy cierpieli bowiem również męscy bohaterowie literaccy. Do tego grona należy m.in. król zwierząt w sporządzonym przez Wojciecha Jakubowskiego przekładzie bajki Jeana de La Fontaine’a Lew chory i lis. O jego dolegliwościach zgodnych 
z tendencjami epoki traktuje sam początek utworu: „Lew król zwierząt leżał chory / Na spazmy czy na wapory"35. Cierpieli na nie zwłaszcza modni kawalerowie. Krasicki w liście 4: Podróż pańska. Do księcia Stanisława Poniatowskiego, nakreślił kapitalny obrazek rodzajowy z młodym kasztelanicem w roli głównej, który to młodzieniec był „Raźny, hoży, rumiany, a z tym wszystkim chory” (w. 26) - właśnie na spazmy i wapory. „Pewnieś chory dla wody” - domniemywa poeta i przedstawia „naturalny” bieg zdarzeń wynikających z przypuszczeń opierających się na powszechnej wówczas tendencji - „a że Karlsbad blisko, / Zaciagnnąeś takowej słabości nazwisko, / Co do Spa zaprowadza" (w. 23-25) ${ }^{36}$. Wydumane choroby stawały się, jak wskazał twórca, jedynie pretekstem do wyjazdów do modnych uzdrowisk europejskich w celach towarzysko-rozrywkowych, dla nawiązania znajomości wśród przebywającej tam elity, a także do wojaży aż do Paryża pod pozorami poszukiwania odpowiednich lekarzy, w aurze nadzwyczajnej troski o zdrowie.

Gwoli sprawiedliwości należy jednak dodać, że w materiałach z epoki mamy także poważne, pozbawione jakiejkolwiek pozy czy ironicznego dystansu notatki poświęcone spazmom. Do tej przykrej dolegliwości z całą powagą odnosił się w swoich wspomnieniach Marcin Matuszewicz. W relacji dotyczącej roku 1758 pisał m.in. o pobycie w Białej, w domu księcia Hieronima Floriana Radziwiłła, chorażego wielkiego litewskiego, gdzie był „bardzo zły stół”, z czym pamiętnikarz powiązał swoje przykre dolegliwości:

Tak tłustych potraw najadłszy się i piwa barzo mętnego złego napiwszy się, na spazmy w piersiach zachorowałem, które przez godzin dwadzieścia sześć $z$ wielkim bólem bez przestanku cierpiałem, aż musiałem posłać księdza Damazego, prezydenta rasieńskiego, do Wołczyna, prosząc o doktora, którego mi zaraz w mojej karecie, którą jeździł ksiądz prezydent, przysłano, i tak ten doktór, Miller nazwany, w jednym dniu od tych bólów mnie uwolnił ${ }^{37}$.

O analogicznych dolegliwościach, wywołanych nagłą i dużą różnicą temperatur, wspomniał też Józef Kopeć - polski oficer, zesłany na daleką Syberię po klęsce insurekcji kościuszkowskiej, etnograf i badacz Kamczatki - w spisanym w 1810 roku dzienniku przymusowej podróży po azjatyckiej części Rosji. W relacji dotyczącej pobytu w okolicach Tobolska opowiedział on o swoim ataku spazmów, krótkotrwałym wprawdzie, ale odczuwanym jako realne zagrożenie życia, chociaż ostatecznie doprowadziło to do dość zabawnej sytuacji. W rozdziale 24 części 4 dziennika, we fragmencie, którego dotyczy anons „Przybycie do Tobolska i dziwaczna choroba spazmów równo z wejściem do ciepłego pokoju"38, narracja oddająca powagę sytuacji dopełniona jest akcentami niemal humorystycznymi:

Ledwom wszedł do ciepłego pokoju, porwały mnie okrutne spazmy; gdyby do tej natury symptoma-

J. de La Fontain e, Lew chory i lis. W: Bajki Ezopa wybrane. Wierszem francuskim [...] ułożone, a przez W. Jakubowski e go, kawalera Orderu Ś[więtego] Ludwika, g. brygadiera wojsk francuskich, polskim językiem z przydatkami wydane. Warszawa 1774, s. 214.

I. Kr a s i c ki, 4. Podróż pańska. Do księcia Stanisława Poniatowskiego. W: Dzieła wybrane. Oprac. Z. Goliński. T. 2. Warszawa 1989, s. 93.

M. Matuszewicz, Diariusz życia mego. Oprac., wstęp B. Królikowski. Komentarz Z. Zielińska. T. 2: 1758-1764. Warszawa 1986, s. 24-25.

J. Ko p éc, Dziennik [...] z rozmaitych not dorywczych sporzadzony, z sześcioma tablicami litografowanymi i mapa Kamczatki. Berlin 1863, s. 223. 
tów mogła wpływać wola, wstyd by był mówić o podobnej chorobie; lecz że dziwactwa pochodzące ze spazmów są powszechnie znane, muszę napomknąć o moim przypadku, który ledwo na wiarę zasługuje.

Mocne uderzenie ciepła na mnie zwątlonego i zaledwo się ruszającego odebrało mi przytomność; zdawało mi się, że nadeszła dla mnie godzina śmierci i że to miejsce jest bardzo do tego wygodne; ostrzegłszy więc gospodarza, położyłem się na wznak, a jego posłałem po księdza. Gospodarz przerażony postacią moją, oznajmiwszy popom, iż ma nieboszczyka w domu, wchodzi z nimi do mojej izby. Przybrani byli oni w kapy, z trybularzem i brewiarzem, w całej gotowości do konduktu. Nim się to wszystko stało, spazmy ucichły, a że już wchodząc do sieni, zaczęli coś śpiewać, uderzony tym wrzaskiem powstałem. Nie widząc trupa, popi pytają, a gdzież nieboszczyk, na to, powróciwszy do przytomności, odpowiadam, że to ja byłem; proszę ich jednak, aby zamiast konduktu prześpiewali Ewangelią. Śpiewanie Ewangelii do łez mnie rozrzewniło, co sprawiło mi ulgę niewypowiedzianą. Poczęstowawszy herbatą $\mathrm{z}$ arakiem moich popów, podziękowałem im za tę chrześcijańską posługę, nareszcie wyszli oni $\mathrm{z}$ całą konduktową świta, a jam został w lepszym już stanie, bo oswojony z powietrzem domowym ${ }^{39}$.

Należy zauważyć, że pamiętnikarz dość szczegółowo ukazał całe wydarzenie, aby nie został posądzony o dziwactwa, jakie w epoce łączono ze spazmami. Taka decyzja wyraźnie wskazuje zarówno na to, iż w owym czasie w polskich realiach spazmy jako zjawisko stricte obyczajowe były powszechne, jak i na stosunek trzeźwo myślących ludzi do wydumanej choroby szerzącej się w kręgu osób z towarzystwa.

W przywołanym uprzednio liście poetyckim Krasicki z wyraźną intencją ironiczno-satyryczna pisze o dość kosztownych, prowadzących do trwonienia, a nierzadko nawet do utraty majątków, pozornych sposobach leczenia udawanych dolegliwości:

Ażeby zdatną czerstwość sprowadził z zagranic,

Spieszy pędem niezwykłym do wód kasztelanic.

Już trzykroć się kurował i trzy wioski stracił.

Cóż po wioskach bez zdrowia? Choć drogo zapłacił,

Więcej zyskał. - Cóż przecie? - Nie do wód on spieszył.

Trzy tylko szklanki wypił, ale się ucieszył,

Ale mód nowych nawiózł, $\mathrm{z}$ książęty się poznał,

Ale wdzięcznych korzyści i awantur doznał,

$[\ldots \ldots \ldots \ldots \ldots \ldots]$

[...] Spazmów i waporów

Nie uleczyły wody, trzeba do doktorów.

Gdzie doktorzy? W Paryżu, gdzież indziej być mogą? [w. 27-41] $]^{40}$

Na dolegliwości związane ze spazmami ówcześni lekarze, oprócz podawania soli trzeźwiących, czyli rozważnego dawkowania gorzkiej, siarczanowej soli angielskiej, oprócz skrapiania tzw. wodą angielską, wodą kolońską, faktycznie zalecali gorące belgijskie źródła lecznicze, wody salcerskie i karlsbadzkie, a także znajdujące się w guberni twerskiej andreapolskie zdroje żelazne, składem chemicznym podobne do pirmonckich, mające własności lecznicze: wzmacniające, skuteczne „zwłaszcza w zastarzałych cierpieniach skórnych, reumatyzmach, spazmach i osłabieniach nerwów"41. Kleofas Szmurło, bohater Podlotka, XIX-wiecznej komedii autorstwa Aurelego Urbańskiego, zapewniał też swoją żonę, że bóle z powodu spazmów miną

39 Ibidem, s. 233.

$40 \quad$ Krasicki, Podróż pańska, s. 93.

41 Encyklopedia powszechna S. Orgelbranda. T. 1: A-Aos. Warszawa 1859, s. 775 (hasło: Andreapolskie zdroje żelazne). 
jej, jeśli położy na ciele „trzy bańki” i „ze dwa kataplazmy” (akt II, sc. 13) ${ }^{42}$, czyli zewnętrzne okłady, wykonywane wówczas najczęściej „z liśsi, kwiatów, owoców, mąk, olejków, tłustości lub gum rozdrobnionych na papkę"43. Zwolenniczką naturalnych, ale też bardziej radykalnych środków zaradczych w przypadku wydumanych modnych dolegliwości była Klementyna Hoffmanowa, która w jednym z komentarzy w powieści Jan Kochanowski $w$ Czarnolesie stwierdziła:

bez wątpienia owa choroba dobrego tonu - którą wiele kobiet udawało, póki jej naprawdę nie dostały - nie byłaby się tak zagęściła u nas zwłaszcza w początkach tego [tj. XIX - B. M.] wieku, gdyby zamiast mówić: „ma słabe nerwy, cierpi spazmy” mówiono po prostu: „dostała kordiaki”, a zamiast przepisać podróż za granicę, do wód modnych, żeby byli nakazali modlić się, pościć, iść do spowiedzi, biczować się ${ }^{44}$.

Domykając ten wątek rozważan, warto przypomnieć, że najpewniejszy, powszechnie dostępny środek zaradczy na modne dziwactwa spazmów i waporów (w przypadku drugiej dolegliwości podany zresztą w przywołanym tu wcześniej haśle Z francuskiej encyklopedii) wskazał Krasicki w swojej pierwszej powieści. W części poświęconej pobytowi Doświadczyńskiego na wyspie Nipu bohater dzieli się taką oto refleksja:

Zabawa rolnictwa jak pożądane za sobą prowadzi skutki, uczułem własnym doświadczeniem. Praca, która z początku zdawała mi się nieznośna, stała się z czasem zabawą przyjemną. Spazmy, wapory, rumatyzmy, $z$ których mnie nie mogły wyprowadzić wody salcerskie i karlsbadzkie, ustapiły dobrowolnie $\mathrm{z}$ rzęsistym potem. Apetyt, który soczystymi bulionami musiał wzbudzać i krzepić $\mathrm{z}$ początku mój kucharz, Chrystian, Niemiec, dalej jegomość pan Sosancourt, Francuz - sam się powrócił; a rzepa po pracy lepiej smakowała niż przedtem podlaskie kuropatwy. [ks. II, rozdz. 7] ${ }^{45}$

Warto nadmienić, że ten sposób leczenia waporów został również podany we francuskiej encyklopedii. Oprócz tego zalecano tam następujące „skuteczne lekarstwa":

$1^{\circ}$. Ścisła dieta, należy jeść jedynie wtedy, gdy odczuwa się głód, i jeść niewiele, unikać potraw pikantnych, likierów, gwałtownych uczuć, bezsennych nocy, gier, a zatem możliwych przegranych, wszelkiej rozwiązłości, należy niewiele chcieć, tylko rzeczy właściwych i możliwych, pracować dużo więcej, niż jeść - są to pewniejsze środki niż wszelkie wzmacniające eliksiry.

$2^{\circ}$. Stworzyć sobie właściwe wyobrażenie własnej niewiedzy i zasług, uznawać się zawsze za wybranka a to fortuny, a to księcia albo natury, $z$ dala od własnych talentów, słuchać rozumu i przestrzegać zasad moralnych - są to zabezpieczenia przed wa por a mi ${ }^{46}$.

Wszystkie osoby, „którym nie spodobaja się te lekarstwa”, odsyłano do kilku pokrewnych haseł, a ponadto jako „środki ratunku” wskazano „lekarstwa oczyszczajace, gorzkie alkohole, aperitify w połączeniu z płynami wzmacniającymi: nalewką ze stroju bobrowego, syropem $z$ bursztynu, tabletkami $z$ katechiny, od Wildegansiusa, i likierem mineralnym od Hoffmana [...]"47.

A. U rb ań s ki, Podlotek. Komedia w czterech aktach, oryginalnie wierszem napisana. Lwów 1867, s. 63.

Lind e, op. cit., t. 2: G-L (1855), s. 334 (hasło: Kataplazma, kataplazm).

K. z Tańs ki ch H off m a n ow a, Jan Kochanowski $w$ Czarnolesie. Obrazy z końca szesnastego wieku. Lipsk 1866, s. 285.

I. Kr a si c ki, Mikołaja Doświadczyńskiego przypadki. W: Dzieła wybrane, t. 2, s. 298.

Encyclopédie, ou Dictionnaire raisonné des sciences, des arts et des métiers, s. 837 (hasło: Vapeurs). Ibidem. 
W odniesieniu do modnych spazmów także skuteczny, aczkolwiek o wiele bardziej drastyczny sposób natychmiastowego przywracania do zdrowia kobiet udających ataki tej przypadłości przedstawił Bogusławski w finale Spazmów modnych. Wtedy to bowiem Służalski miał możliwość wypróbowania w przypadku swojej żony (omdlewającej „z żalu i rozpaczy” na wieść o rozłące z Wiernickim) lekarstwa, jakie dla służby na te „okolicznościowe” przypadłości na pokaz zapisał „nieoszacowany Doktor”. Na widok dużej dyscypliny do kar cielesnych Dorotka natychmiast odzyskała równowagę:

SŁUŻALSKI

Jużeś ozdrowiała? (całując dyscyplinę) O błogosławione, o warte ozłocenia lekarstwo. Kochany Doktorze, jakże ci to odwdzięczyć potrafię?

DOROTKA

Jakąż to receptę dał wam ten przeklęty Doktor? Zaspokój ciekawość moję...

SŁUŻALSKI

Chcesz ją widzieć? Oto jest (wyjmuje papier $z$ kieszeni). Kiedykolwiek przyjdzie ci pokusa spazmy albo mdłości udawać, przeczytaj ją, a ozdrowiejesz natychmiast. - O jak wiele małżeństw żyłoby dziś w spokojności i zgodzie, gdyby mężowie chcieli używać tej recepty dla żonek! Słuchaj (czyta):

To jest na modne spazmy recepta jedyna:

Dla pań powaga męża, dla sług dyscyplina. [akt III, sc. ostatnia $\langle 15\rangle]^{48}$

W końcowym zaleceniu pisarz wykorzystał podwójne znaczenie słowa „dyscyplina” - i jako posłuszeństwa, i jako narzędzia kary cielesnej. Do tej ostatniej Służalski odwołał się zresztą już wcześniej, na samym początku sztuki, mówiąc o naturalnym, a przy tym skutecznym środku zaradczym na spazmy żony swego pana:

Oj, żebym ja był Panem Hrabią, dałbym ja jej brzozowy kordyjał, który by ją na zawsze uleczył. [akt I, sc. 1] ${ }^{49}$

Poświęcone udawanym spazmom i waporom interwencyjne wypowiedzi pisarzy w dobie stanisławowskiej wynikały z potrzeby tamtej epoki. Stanowią one - utrzymaną w ironiczno-satyrycznym bądź krytycznym tonie - swego rodzaju dokumentację literacka aktualnych zjawisk obyczajowych, mody (zatem konkretnego przejawu stylu życia), a szerzej: specyficznych cech ówczesnej kultury, związanych ze środowiskiem miejskim, zwłaszcza stołecznym, przedstawicieli wyższych warstw społecznych. Do takich intencji pisarzy stanisławowskich odwołał się Ludwik Zieliński w wierszu dedykacyjnym do „Jaśnie Wielmożnej” hrabiny A. P., którym opatrzył wydany w roku 1833 zbiór Satyry i bajki. W wypowiedzi utrzymanej w konwencji narzekania na „świat zepsuty” autor wspomina także o koniunkturalnej, wymuszonej przez niedostatek przemianie jednego z niegdysiejszych „chudych literatów":

\footnotetext{
Wszakże nasz Michał, co się z prawdą szerzył,

Po długim poście w pochlebstwo uwierzył.

Dawniej modzie przyganiał, co sam wyznać muszę,

Gdy nam fraki wyklinał, a sławił kontusze.

Był człowiek wcale inny, krytyków nie szczędził,
} 
Nieraz spazmy i mdłości wierszami rozpędził, Gdy jął starym przyganiać, na młodych wyrzekać,

A każdy, co go słuchał, zmuszony uciekać,

Po drodze, gdy pytano, rozumu nie przeczył,

I nieraz siebie, drugich $z$ głupoty uleczy $1^{50}$.

Wbrew pozorom - w piśmiennictwie polskim drugiej połowy XVIII wieku nie ma zbyt wielu przywołań sytuacji i osób, które ośmieszałyby uzewnętrzniane w spazmach czy waporach ludzkie słabości oraz śmieszności, chociaż oba zjawiska uznaje się za jedne $z$ charakterystycznych elementów ówczesnej obyczajowości wyższych warstw. Do spopularyzowania problemu tych pozorowanych dolegliwości, przede wszystkim spazmów, w naszej rodzimej literaturze kilku początkowych dekad XIX stulecia, zwłaszcza w obszarze komedii, zdecydowanie przyczyniła się sztuka Bogusławskiego, będąca niezbyt udaną, jak dowodzi Eugeniusz Kucharski, przeróbka jednoaktowej farsy włoskiej Le convulsioni (Spazmy), napisanej przez Francesca Albergatiego Capacellego około $1780 \mathrm{roku}^{51}$. Premierowa inscenizacja tego utworu i zarazem jedyna przed publikacją w zbiorowej edycji dzieł polskiego twórcy przeszła bez echa, nie odniosła też sukcesów na scenie w następnym stuleciu. W wersji drukowanej szeroki rezonans w dużej mierze uzyskała, jak się wydaje, dzięki przywoływanej już wstępnej wypowiedzi Bogusławskiego. Bardzo wyraźne nawiązania do utrwalonego w Spazmach modnych pobłażliwie żartobliwego traktowania odgrywanych przez kobiece bohaterki ataków wskazanej w tytule dolegliwości i schematycznego ujmowania w dziełach scen $\mathrm{z}$ tym się łączaccych odnajdujemy w XIX-wiecznych komediach pisanych według oświeceniowych wzorców.

Takie rozwiązanie zastosował np. Stanisław Jaszowski w finale komedii Dom modny, akcentując wydumany charakter panieńskich spazmów. Gdy okazuje się, że Bogacki ze szczerej miłości wybrał na żonę cnotliwą Amalię, a Baron Wietrznicki pannę kasztelankę, liczace na te partie zmanierowane córki Starosty - Eufrozyna i Ludmiła - reagują zgodnie $z$ wyobrażeniami o damach modnych $z$ towarzystwa. Druga $\mathrm{z}$ nich, $\mathrm{z}$ iście teatralną pozą, zanim opadnie na krzesło, wykrzykuje: „Ach! słabo mi, dla Boga! Ach! słabo mi, mdleję!" (akt III, sc. 14) ${ }^{52}$. A gdy Eufrozyna osuwa się na drugie krzesło w równie teatralnym omdleniu, poprzedzonym ostrzeżeniem: „Uczuwam spazmy, serce drży we mnie, drętwieje”, na wołanie przestraszonego służącego Jeana nadbiega służąca Agatka i przystępuje do „trzeźwienia” obu kobiet, jakby z oczywistością komentując zaistniałą sytuację: „Nie ma niebezpieczeństwa, ot, spazmów dostały!" (akt III, sc. 14) ${ }^{53}$.

Kilkakrotnie do upowszechnionych wyobrażeń o tej dolegliwości nawiązał w swoich tekstach scenicznych Wincenty Thullie. Do udawanych spazmów jako szantażu emocjonalnego, sposobu wymuszania na mężu konkretnego postępowania ucieka się dama modna o imieniu Eliza, bohaterka jednoaktówki Zwierciadło,

L. Zi eliń ski, Do JW. hr. A. P. W: Satyry i bajki. Lwów 1833, s. 4-5.

Zob. porównanie obu sztuk: E. Ku charski, Wojciecha Bogusławskiego „Spazmy modne”, „Pamiętnik Literacki” 1925/26, z. 1/4, s. 191-201.

Z. J a s zow ski, Dom modny. Komedia we trzech aktach wierszem, napisana roku 1824. W: Zabawki rymotwórcze. T. 3. Lwów 1826, s. 72.

Ibidem, s. 73. 
która w scenie 6 skarży się, że ją kochający mąż Henryk w domu „trzyma jak w klasztorze" - bez spacerów, wizyt w teatrze, udziału w balach. Z prawdziwie aktorskim talentem odgrywa przed nim nawrót ataku migreny, zaczynając od ekspresywnych zawołań: „Ach! słabo mi, ach! słabo!”54. Na zapytanie Wacława, z którym została sam na sam - czy powzięte zadanie było trudne, odpowiada:

\section{ELIZA}

Może dla waćpana

Napadła mię migrena, w spazmach się męczyłam I tak zręcznie mężulka $z$ domu wyprosiłam ${ }^{55}$.

Nic dziwnego, że Wacław podziwia ją za presens d'esprit - trzeźwość umysłu. Z kolei w jednoaktówce tego samego autora Nieporozumienie pannę Julię, zdenerwowaną wiadomością, że Ludwik, którym jest zainteresowana, nie będzie czynił wobec niej żadnych umizgów, że nie podejmie żadnych form sztucznego rytuału miłosnego, jej matka, pani Poczciwska, opisuje jako uosobienie salonowej mody. Ma przy tym nadzieję, że córka przyciagnie uwagę bywającego u nich w domu Barona. W dwóch ostatnich wersach przytoczonego tu tekstu odnajdujemy bardzo wyraźne, słowne (spazmy, moda) i rekwizytowe (perfumy, kolońska woda), nawiązanie do sztuki Bogusławskiego:

\section{MATKA}

Teraz mi się podobasz, wyglądasz inaczéj.

Baron będzie zachwycon, gdy ciebie zobaczy.

Co to za gust w ubraniu, sukienka morowa,

Włosy a la żyrafa, kokarda pąsowa.

A ta irytacyja, coś z Ludwikiem miała,

Nowego jeszcze blasku wdziękom twym dodała.

Wybornie! Gdzież perfumy, gdzie kolońska woda?

Udawaj, że masz spazmy, taka dzisiaj moda. [sc. 10] ${ }^{56}$

Według analogicznego schematu Pan Grzybek, myślaccy o ożenku tytułowy bohater komedii Stary kawaler, wyobraża sobie kobiety, które w małżeńskim stanie są utrapieniem dla mężczyzny. Wśród wydumanych dolegliwości, zadręczających osoby $z$ otoczenia, pisarz pomieścił też spazmy i wapory, chociaż ta ostatnia nazwa nie pada:

STARY KAWALER
W prawdzie wszystkie są złośliwe,
Próżne, zalotne, kłótliwe;
Wszystkie prawie w jedną porę,
Choć nie leżą, jednak chore.
Ta narzeka na ból głowy,
Tamtę łamie do połowy,
Ta ma spazmy, ta w migrenie,
Ta zaś cierpi serca drżenie,
Ta przesypia wszystkie ranki,

W. Thulli e, Zwierciadło. Komedyja w jednym akcie, podług Marsana, wierszem. W: Komedyje. T. 1. Lwów 1833, s. $63,61$.

Ibidem, s. 63.

W. Thulli e, Nieporozumienie. Komedyja $w$ jednym akcie oryginalna, wierszem. W: Komedyje, t. 1, s. 16 . 
Tamta zrywa się po rosie,

Wszystkie niby to baranki,

Gdyby nie te muchy w nosie ${ }^{57}$.

Należy zauważyć, że w utworach tego czasu dochodzi do znamiennego jakościowego przesunięcia znaczeniowego. Spazmy i wapory - pierwotnie postrzegane jako aktualne zjawisko obyczajowe i swego rodzaju modne „dziwactwo”, które ośmieszano, wystawiając je na widok publiczny w celach żartobliwych bądź krytycznych - w rzeczywistości nowej epoki ulegają leksykalizacji jako swoisty relikt zanikającej, odchodzącej kultury i stają się obiegowym motywem literackim, rekwizytem o ściśle ustalonym znaczeniu. Służy on przede wszystkim eksponowaniu i wzmocnieniu zabiegów teatralizacji konkretnych scen i celowo przerysowanych, przesadnych zachowań bohaterów, m.in. związanych z miastem, a zwłaszcza z kręgiem salonowym - nie tylko w komediach, ale także w tekstach epickich.

Szczególnie wyraziście taka właśnie funkcja owego rekwizytu ujawnia się, gdy postaci na scenie lub w opisanych sytuacjach komentują swoje zachowanie i używają podwojonych zawołań. „Spazmy! Spazmy!”, np. w komedii Warszawiacy $i$ hreczkosieje (1857) Antoniego Wieniarskiego. Mamy tu do czynienia z tym ciekawszą teatralizacją wspomnianego zabiegu, że dotyczy ona nie kobiety, lecz jednego z konkurentów do ręki posażnej młodej wdowy - Pani Żarskiej. A jest nim przybyły na wieś modny kawaler Ewaryst, „paniątko wychuchane, wygłaskane, wypieszczone. Pokaż mu kota, to ucieknie, a dmuchaj dobrze, to się wywróci!" (akt I, sc. 7) ${ }^{58}$. Tenże to „paniczyk, goluteńki jak turecki święty” 59 , po nieoczekiwanym zetknięciu się z żabą w czasie ogrodowej drzemki w wiejskiej posiadłości podwarszawskiej pułkownika Macieja Starży, przestraszony i zdenerwowany, tak z irytacją swój stan komentuje i zarazem opisuje zarządcy domu, Bartłomiejowi Ziembie:

\section{EWARYST \\ (wpada przerażony - blady)}

Trzęsę się cały z przerażenia - z irytacji. Muszę być niezmiernie blady - wszystkie nerwy we mnie drżą (przykłada rękę do serca). $\mathrm{O}$ - o, jak mi serce bije! (łapiąc oddech) $\mathrm{O}$ - tchu mi wyraźnie brakuje. Spazmy! spazmy! - wody, kto w Boga wierzy - umieram!

\section{ZIEMBA}

Pan umiera? Co się stało?

EWARYST

Umieram - mogę u mrzeć! Mój stary - ratuj - ratuj mnie. [akt I, sc. 8] ${ }^{60}$

Podobnie w przywoływanej już komedii Urbańskiego jedna z bohaterek, komentując swoją nadwrażliwość na zapachy, z afektacją woła: „Ach! ach! - spazmy! spazmy!..."61. Ostrzegające okrzyki Delfiny przyjęte sa jednak ze spokojem, co dobitnie wyraża rada udzielona jej przez Kleofasa: „To nic! - Połóż z trzy bańki - ze dwa kataplazmy, / To ustanie" 62 .

W. Thulli e, Stary kawaler i odkosze (intermezzo). Naśladowanie wierszem. W: jw., s. 111.

A. Wi en iars ki, Warszawiacy i hreczkosieje. Komedia $w$ trzech aktach ze śpiewkami. (Przedstawiona na Warszawskim Teatrze Rozmaitości w r. 1857). Warszawa 1857, s. 21.

Ibidem.

Ibidem, s. 23.

Urbański, op. cit., s. 63 .

Ibidem. 
Sygnalizowane rozwiązania artystyczne w kreacji postaci znakomicie ilustruje także fragment powieści Fryderyka Skarbka Pan Starosta (1826):

Po półgodzinnym przeszło oczekiwaniu otworzyły się drzwi szeroko i weszła, przechylając się z jednej na drugą stronę, pani hrabina z cierpiącym uśmiechem na twarzy, przywitała słodziuteńko i matkę, i córkę, a poprawiając przed lustrem włosy, narzekała na słabość, na ból głowy i okropne spazmy, których świeży rumieniec najlepszym był dowodem. Za jej przykładem zaraz i panią kasztelanową głowa zabolała, dostała szumu w uszach i była bardzo cierpiąca, zwłaszcza że nigdy sypiać nie mogła ${ }^{63}$.

Z kolei w obyczajowej powieści Dziwadła (1853), rozgrywającej się w środowisku prowincjonalnej szlachty, Józef Ignacy Kraszewski na wzór oświeceniowej damy modnej wykreował postać pięknej, ale rozpieszczonej, próżnej, lekkomyślnej i samolubnej Teresy, dla której histeryczny płacz był jedną z form szantażu, jakim starała się wymusić na mężu, Grabie, różne zachcianki i przyjemności:

Piękna Terenia nudziła się sobą, mężem, światem, potrzebowała zabaw, podróży, strojów, lekkich książek, co drażniąc wyobraźnię nie nasycają głowy, przędą z serca uczucia fałszywe. Powolnie wprawdzie, ale stanowczo Graba oparł się jej pragnieniom, chcąc jej przywrócić zdrowie ruchem, pracą, zajęciem użytecznym, chcąc ukołysać wyobraźnią, zbliżając ją do rzeczywistego życia. [...] Ale piękna Teresa, pieszczone dziecię, słuchać tego nie chciała, płakała, chorowała, dostawała spazmów, a gdy w końcu paradne cugi, szamerowane liberie i kucharz Francuz ustapić musieli skromniejszemu urządzeniu domu, wymówiła straszny wyraz - rozwód ${ }^{64}$.

Dodajmy, że również Michał Czajkowski w opowieści historycznej Kto z Bogiem, to Bóg z nim z cyklu Ukrainki (1841) bardzo trafnie wykorzystał różne dziwactwa obyczajowe minionej epoki w celu wzmocnienia karykaturalnych rysów liczącej lat 56 panny jako zdziwaczałej, „zbabiałej” damy modnej:

Panna Salomea kiedyś była sławna na całe okolice: jak łania dziewica, liczko gładkie, podostatek urody i posag szlachecki; byłaby znalazła męża, ale na nieszczęście tańczyła jakieś tam menuety, almandy; paplała ciągle pstrokatą mową, między polskie mieszając francuskie wyrazy; czytała i duszą się rozpływała nad ksiażkami panny Skudery, pani de Żanlis, pani Kotten, ukradkiem poznała się z Wolterem; [...] do kościoła stroiła się jak na teatr i w kościele jak w teatrze się krygowała; często gęsto ją napadały spazmy, migreny, supiry i diabli wiedzą jakie słabości, o których nigdy ucho polskie nie zasłyszało; ani pytać ją było o to, co się dzieje w gospodarstwie domowym, bo zaraz by jakiego supira albo spazma ucięła, a chcieć, żeby w pogodny dzień w bryczce na resorach, a nie w karecie jechała, zaraz by wystapiła $\mathrm{z}$ migreną $[\ldots]^{65}$.

Wyraźnym sygnałem przewartościowania $z$ czasem tego rodzaju literackich wzorców i pomysłów, nawet tych wykorzystywanych w celach karykaturalnych, jest zainteresowanie się u nas już u początków wieku XIX spazmami i waporami jako konkretnymi, rzeczywistymi schorzeniami, a zatem problemem stricte naukowym filozoficznym i medycznym. Świadczy o tym choćby publikacja w „Tygodniku Wi-

F. Sk a r b e k, Pan Starosta. T. 1. Warszawa 1826, s. 22-23.

64 J. I. Kraszews ki, Dziwadła. Powieść wspótczesna. Kraków 1964, s. 163-164. W Słowniku warszawskim początkowa część ostatniego z cytowanych zdań (wyjąwszy wyrazy „słuchać tego”) ilustruje drugie z podanych znaczeń nazwy „spazm” (zob. przypis 7). Fragment ten, z powołaniem się na słownikowe źródło, bezrefleksyjnie, w kuriozalnej postaci przytacza w swym artykule K ró tki (op. cit., s. 80; podkreśl. - B. M.): „Piękna Teresa pieszczonych dzieci nie chciała, płakała, chorowała, dostawała spazmów".

65 M. C zajkow ski, Ukrainki: Kto z Bogiem, to Bóg z nim. W: Pisma. Wyd. 2, przejrz. i popr. T. 7: „Koszowata” i „Ukrainki”. Lipsk 1865, s. 152. 
leńskim" w lipcu 1804 przekładu fragmentów francuskiego tekstu: De Lichtenberg, des vapeurs et de la connaissance de soi-même, w styczniu owego roku zamieszczonego w paryskim piśmie „Archives littéraires”66. Do „waporów” tłumacz dodał w przekładzie nazwę drugiej dolegliwości: $O$ spazmach, waporach $i$ o poznaniu siebie; tudzież o profesorze Lichtenbergu stosownie do tej materyi ${ }^{67}$. Jeśli nie liczyć komedii, w nowej epoce i w następnej w tekstach literackich, głównie w powieściach, spazmy przywoływano i w konkretnych scenach opisywano jako rzeczywiste schorzenie przysparzające dotkliwych cierpień, przejawiające się u kobiet $(\mathrm{z}$ racji przekonania o ich słabej konstrukcji psychicznej i emocjonalnej) w chwilach nagłego wzburzenia konwulsyjnymi atakami nerwowymi - aż do utraty przytomności.

Przypisaną w pewien sposób kobietom w XVIII wieku skłonność do spazmów utrwalił, bez ironicznych czy satyrycznych intencji, lecz przeciwnie $-z$ cała powaga eksponując emocjonalną, nerwową nadwrażliwość przedstawicielek płci pięknej o artystycznej duszy, Włodzimierz Wolski w debiutanckim przekładzie opowiadania Don Juan. Zdarzenie zapaleńca $w$ podróży autorstwa niemieckiego pisarza i kompozytora Ernsta Theodora Amadeusa Hoffmanna, od roku 1800 związanego z Poznaniem. W zakończeniu utworu rozmowa toczy się o aktorce, która w teatrze sąsiadującym $z$ hotelem, gdzie zatrzymał się narrator, w operze Mozarta odgrywała $z$ autentycznym przejęciem i rozczuleniem swoją rolę. Jeden $z$ gości, ,Z twarzy podobny do mulata", komentuje:

O! nieraz ją przestrzegałem. Zazbyt przejmowała się zawsze rolą Donny Anny. Wczoraj była jak obłąkana. Cały między-akt mdlała, a w scenie aktu II miała spazmy nerwowe. [...]

[...] Tak, spazmy nerwowe, że jej nie można było wynieść ze sceny ${ }^{68}$.

$\mathrm{W}$ odpowiedzi na tę relację, zapewne w związku z powszechnym pobłażliwym przekonaniem, że to dolegliwości urojone, udawane, a nawet jeśli faktyczne, to niegroźne, narrator komentuje: „Na miłość boską, wszak spazmy nie tak niebezpieczne - niedługo znów Signorę ujrzemy?” Na co „mądry z tabakierką” reaguje ripostą: „Wątpię bardzo, bo Signora dzisiaj punkt o drugiej godzinie rano - umarła”69.

W powieści Zygmunta Kaczkowskiego Wnuczęta (1855) spazmy również służą udramatyzowaniu kilku scen. W tym celu pisarz posługuje się dwiema metodami.

E. H., De Lichtenberg, des vapeurs et de la connaissance de soi-même. „Archives littéraires de l'Europe ou Mélanges de littérature, d'histoire et de la philosophie. Par une société de gens de lettres, suivis d'une gazette littéraire universelle" t. 1 (1804). W tym numerze o waporach traktuje także tekst A. Morellet a De l'esprit de contradiction.

67 O spazmach, waporach i o poznaniu siebie; tudzież o profesorze Lichtenbergu stosownie do tej materyi. „Tygodnik Wileński” 1804, nr 11 (z 2 VII), s. 152-159; nr 12 (z 9 VII), s. 171-176; nr 13 (z 16 VII), s. 186-194. W tekście mowa jest o cierpiącym na hipochondrię (męską „odmianę” waporów) lekarzu, który „pozostawił po sobie dzieła bardzo dowcipne”. Autor skupił się jednak nie na spuściźnie, ale na charakterze Lichtenberga, opisanym w jego dzienniku: „przez słabość swego temperamentu poddany wzruszeniom nerwowym, których prawie bez ustanku doznawał; wśród bólów, dziwactw i przykrych uczuciów, które takowa kompleksja za sobą wiedzie, Lichtenberg umiał zachować w sobie zdolność ich uważania, pewnej im naznaczenia przyczyny i poznania ich wpływu zwodniczego, chociaż żadną miarą nie mógł się im odjąć” (ibidem, nr 11, s. 155-156).

68 E. T. A. H off m a n n, Don Juan. Zdarzenie zapaleńca w podróży. Przeł. W. W [o ls k i]. „Biblioteka Warszawska” 1842, t. 4, s. 328. 
Bez jakiegokolwiek komentarza wymienia np. tę dolegliwość w ciągu wyliczeniowym z innymi symptomami zachowania świadczącego o krótkotrwałym, lecz dużym nasileniu stanów emocjonalnego i nerwowego pobudzenia. M.in. takie wyliczenie stosuje pisarz, charakteryzując niezwykłą, nad miarę egzaltowaną, nadpobudliwą osobowość Ernestyny, wychowywanej przez ojca dziwaka:

Najdziwaczniejsze myśli pod słońcem, niewidziana egzaltacja umysłu, najzawilsza mieszanina równie egzaltowanych uczuć w sercu, niesłychana drażliwość nerwów, wiara w sny, duchy i proroctwa, wizje nocne i dzienne, przeczucia i przywidzenia, a do tego lunatyzm i spazmy, owóż są części pojedyncze, $\mathrm{z}$ których się składa moralna istota tej kobiety ${ }^{70}$.

Silnymi akcentami dramatycznymi naznaczona jest z kolei relacja, w której narrator wspomina o spazmach, opisując krańcową reakcję Ernestyny po straszliwej awanturze, jaką urządził jej niegdysiejszy kochanek:

pani Ernestyna stała chwilkę jak osłupiała, drżąc na całym ciele i oddychając coraz gwałtowniej i nienaturalniej. Niebawem atoli drżenie to zaczęło się powiększać i przechodzić w formalne drganie członków całego ciała, co dawało widok nader niemiły, bo całkiem do konwulsyj podobny. Tymczasem nie były to konwulsje, tylko spazmy tak silne, które przy swoim usposobieniu nerwowym często cierpiała ta nieszczęśliwa kobieta. Na to cierpienie nie masz żadnego lekarstwa. [...]

[...] Po godzinie ustał paroksyzm spazmów i nastapiło owo przesilenie się cierpienia, po którym następuje tylko osłabienie całego organizmu i rodzaj bolesnego snu na jawie ${ }^{71}$.

Z cała powagą ukazany tu został rzeczywisty atak nerwowy, sprowadzajacy na nieszczęsną kobietę straszliwe cierpienia - w niczym nie przypomina on wydumanej, teatralnej pozy modnych dam i kawalerów.

Bolesne przeżycia bohaterek, nierzadko skrywane przed otoczeniem, umożliwiały im dogłębne poznanie samych siebie. Ponadto wzmacniały dramatyczne rysy wewnętrznego portretu postaci, ich wizerunku emocjonalnego, psychologicznego i duchowego. Tego typu ujęcia dalekie były od naśladowanych schematów, świadczyły o stosowaniu w kreacji bohaterów literackich nowych rozwiązań, uwzględniajaccych problemy ludzkiej psychiki i sfery emocjonalnej.

\author{
Abstract \\ BOŻENA MAZURKOWA University of Silesia, Katowice \\ ORCID: 0000-0003-3546-6583
}

\title{
SPASMS AND VAPOURS IN THE $18^{\text {TH }}$ AND $19^{\text {TH }}$ C. POLISH WRITERS' LITERARY CREATIONS
}

The study presents the then fashionable among the society's imagined illnesses of ladies and cavaliers, referred to as spasms and vapours, recorded in the works of the Polish Enlightened authors. Rich in affectation manifestations of the complaints were symptoms of upper classes representative's lifestyle, and were seen as distinctive customary trait of the epoch and culture of that time. The author gives a succinct description of the modes, stamped with humour, irony or critical distance, of referring to the stylish symptoms found in the pieces composed at the times of Stanisław August Poniatowski and popularised by Wojciech Bogusławski's comedy Spazmy modne (Stylish spasms, 1797). She traces the 
vitality of the motif in question in the $19^{\text {th }}$ century literature, pointing at a continuation of traditional approaches and at the new artistic solutions that provide for transformation of the initial customary phenomenon into a common literary motif that serves to strengthen the theatricalisation of given scenes and exaggeration of protagonists' behaviours. She also pays attention to the ways spasms are employed to the epic texts to accentuate the dramatic traits of persons' internal portrait, and their emotional, psychological, and spiritual image. 